\title{
Permainan Tradisional Boy-boy an Berpengaruh pada Perkembangan Sosial Anak Usia Dini
}

\author{
Aisyah \\ Fakultas Pedagogik dan Psikologi Universitas PGRI Adibuana Surabaya \\ Email : aisyah@unipasby.ac.id
}

\begin{abstract}
Abstrak
Penelitian ini dilatarbelakang oleh fakta bahwa anak-anak di grup B mengalami kesulitan dalam mengasah kemampuan mereka untuk mematuhi aturan permainan, empati, bekerja sama, tanggung jawab, bermain dengan rekan-rekan, menunggu giliran mereka untuk bermain dan persaingan yang adil. Penelitian ini dilakukan dengan sampel 25 anak berusia 5-6 tahun. Teknik sampel yang digunakan adalah post test dan pres test. Pengumpulan data penelitian ini menggunakan instrumen uji, observasi, dan dokumentasi yang dianalisis secara statistik oleh Design One Group Pre-Test dan post test. Teknik analisis data yang digunakan untuk menguji hipotesis penelitian ini adalah t-test. Dari data yang dikumpulkan dan dari hasil perhitungan data dapat diketahui atau menunjukkan bahwa perkembangan sosial setelah diperlakukan dengan permainan tradisional boy-boyan memiliki pengaruh dengan peningkatan 2,95 sedangkan skor sebelum dirawat oleh permainan tradisional boy-boyan adalah 2.62. Dan berdasarkan hasil tes t-count nilai yang diperoleh (7.431) lebih besar dari tabel t (1.711) dengan tingkat signifikansi 5\% berarti ada pengaruh signifikan antara permainan boy-boy tradisional pada perkembangan sosial pada anak kelompok B Muslimat NU TK 79 Jemundo Taman Sidoarjo.
\end{abstract}

Kata kunci : permainan anak laki-laki tradisional, perkembangan sosial, anak usia dini

\begin{abstract}
This research is motivated by the fact that children in group B have difficulty in honing their ability to obey the rules of the game, empathy, working together, responsibility, playing with peers, waiting their turn to play and fair competition.This research was conducted with a sample of 25 children aged 5-6 years. The sample technique used was post test and pres test. The data collection of this study uses test, observation, and documentation instruments which are analyzed statistically by the Design One Group Pre-Test and post test.The data analysis technique used to test the hypothesis of this study is t-test. From the collected data and from the results of the calculation of the data can be known or show that social development after being treated with traditional boyboyan games has an influence with an increase of 2.95 while the score before being treated by traditional boyboyan games is 2,62. And based on the test results of the t-count test obtained value (7,431) greater than t table $(1,711)$ with a significance level of 5\% means that there is a significant influence between traditional boy-boy games on social development in children group B Muslimat NU Kindergarten 79 Jemundo Taman Sidoarjo.
\end{abstract}

Keywords : traditional boy-boy games, social development, early childhood

\section{PENDAHULAN}

Pendidikan anak usia dini adalah suatu jenjang pendidikan yang mendasar sebelum Pendidikan yang lebih tinggi, usia peserta didiknya berkisar di antara usia 3-6 tahun. Pendidikan Anak usia Dini dipersiapkan untuk membantu pertumbuhan dan perkembangan fisik dan psikis anak supaya memiliki kesiapan dalam memasuki pendidikan lebih lanjut, yang di selenggarakan pada jalur formal,nonformal, dan dan informal yang sesuai dengan (UU No.20 tahun 2003,pasal 1 ayat 14)

Tujuan pendidikan anak usia dini yaitu untuk membentuk anak indonesia yang berkualitas, yang seuai dengan tingkat pertumbuhan dan perkembangannya sehingga memiliki kesiapan yang optimal di dalam memasuki tingkat pendidikan yang lebih tinggi untuk masa depannya. Prinsip-prinsip yang di 
WAHANA

Volume 72, Nomor 2, Desember 2020 kembangkan dalam pendidikan anak usia dini antara lain:

(1) Prioritaskan kebutuhan anak; (2) Yang bermain seraya belajar; (3) Lingkungan yang mendukung dan menantang; (4) Menggunakan pembelajaran komprehensif dalam permainan (5) Mengembangkan berbagai keterampilan atau kecakapan hidup 6) Menggunakan berbagai media atau permainan edukatif dan sumber belajar; (7) Ulangi langkah demi langkah.

Aspek perkembangan anak meliputi perkembangan moral, kognitif, bahasa, gerak fisik, dan nilai-nilai sosial emosional. Untuk mencapai perkembangan yang seimbang antara satu aspek dengan aspek lainnya, terutama perkembangan sosial anak, semua aspek perkembangan menjadi sangat penting.

Menurut pengamatan awal penulis pada kelompok B di TK Muslimat NU 79 Miftahul Huda jemundo sejumlah 25 anak, perkembangan sosial anak seperti mentaati aturan bermain, bermain dengan teman sebaya, menunggu giliran bermain dan mampu bersikap berkerjasama dengan teman sangat kurang.

Kemampuan ini berkaitan dengan kemampuan anak dalam bersosialisasi dengan lingkungan sekitarnya. Anak yang dapat bersosialisasi dengan baik diharapkan memiliki keterampilan sosial yang lebih baik dibandingkan dengan anak yang mengalami kesulitan bersosialisasi dengan lingkungan sekitarnya. Anak dengan keterampilan sosial yang baik akan berinteraksi dengan baik dengan orang lain, dapat memahami orang lain dengan berbagai cara saat menghadapi masalah, dapat merasakan perasaan orang lain dan dapat bekerjasama dengan baik.

Secara umum permainan tradisional dapat menjadi sarana untuk mengembangkan dan melatih keterampilan sosial anak, karena permainan merupakan bagian yang tidak terpisahkan dari anak. Anak-anak akan merasa senang dan tenggelam dalam permainan tersebut, sehingga mereka tidak menyadari bahwa permainan tersebut adalah belajar melatih keterampilan sosial.

Game merupakan upaya memberikan pengalaman dan kesempatan tanpa dibatasi oleh waktu dan aturan main, sehingga anak memiliki banyak waktu untuk eksplorasi dan pengembangan pengetahuannya sendiri (Fauziddin, 2015). Bergaul dengan pasangan
Anda, Anda dapat memahami perilaku Anda sendiri, dan memahami bahwa setiap tindakan memiliki konsekuensinya. Perkembangan sosial merupakan proses belajar kemampuan dan perilaku yang berkaitan dengan kehidupan individu (Aisyah, 2012). Pembangunan sosial merupakan proses pembelajaran yang perlu menyesuaikan dengan norma, etika dan tradisi kelompok, menjadi satu kesatuan, saling berkomunikasi, dan bekerja sama (Yusuf, 2015).

Permainan tradisional merupakan permainan yang diturunkan dari satu generasi ke generasi berikutnya yang mempunyai nilai baik, positif, bernilai dan ideal. Permainan tradisional adalah kegiatan yang diatur oleh aturan permainan yang diwarisi dari generasi sebelumnya untuk kesenangan.

Menurut penelitian Pradana (2013), Boyboyan merupakan permainan tim tradisional yang menggunakan bola untuk menghancurkan sasaran dari tumpukan batu bata, pecahan batu bata atau pecahan ubin lantai.

\section{METODE PENELITIAN}

Penelitian ini menggunakan metode design uji beda hasil pre test dan pos test untuk satu kelompok yang disebut one group pre and post test design.

Populasi dalam penelitian ini adalah anak usia dini kelas B usia 5-6 tahun berjumlah 25 anak terdiri dari 12 perempuan dan 13 laki-laki di TK Muslimat NU 79 Miftahul Huda Jemundo Taman Sidoarjo menyertakan seluruh subjek (total populasi) berjumlah 25 anak untuk menepatkan variabel sebenarnya dengan melibatkan satu kelompok tanpa adanya kelompok pembanding atau tanpa menggunakan kelas kontrol karena kelompok B tersebut hanya satu kelas.

Pengumpulan data penelitian ini menggunakan instrument tes, observasi dan dokumentasi. Penelitian ini di analisis dengan menggunakan analisis statistic (pre-experiment) dengan desain the one group pretest-postetest.

\section{HASIL PENELITIAN}

Hasil yang diperoleh dalam penelitian ini adalah ada pengaruh permainan tradisional boyboyan terhadap perkembangan sosial pada anak 
WAHANA

Volume 72, Nomor 2, Desember 2020 kelompok TK B Miftahul Huda Jemundo Taman Sidoarjo dengan jumlah 25 anak. Hal tersebut dapat diketahui dengan adanya peningkatan perkembangan sosial setelah diberikan perlakuan dengan kegiatan permainan tradisional boy-boyan yang memiliki pengaruh dengan peningkatan sebesar 2.95 sedangkan skor sebelum diberi perlakuan kegiatan permainan tradisional boy-boyan sebesar 2,62. Dan berdasarkan uji $\mathrm{t}$ hitung diperoleh nilai $(7,431)$ lebih besar dari t tabel dengan taraf signifikansi $0.05 \quad(1,711)$ dan dengan taraf signifikansi 0.01 (2.492). Dimana Hipotesis Nol ditolak dan Hipotesis Kerja diterima yang menyatakan Permainan Tradisional Boy-Boyan Terhadap Perkembangan Sosial Pada Anak Kelompok B TK Muslimat NU 79 Miftahul Huda Jemundo Taman Sidoarjo.

\section{PEMBAHASAN}

Berdasarkan hasil penelitian alat permainan tradisional boy-boyan data membuat anak menjadi senang serta dapat meningkatkan perkembangan social anak.

Menurut Santi (2009), perkembangan sosial menitik beratkan pada identitas anak, hubungan satu sama lain, dan pemahaman mereka terhadap lingkungan tempat tinggal dan kondisi sosial anak.

Mengetahui Peningkatan pengaruh permainan tradisional boy-boyan terhadap perkembangan sosial anak dalam penelitian ini dikarenakan adanya untuk mengasah kemampuan sikap mentaati aturan permainan, empati, bekerja sama, tanggung jawab, bermain dengan teman sebaya, menunggu giliran untuk bermain dan persaingan sehat.

Bermain merupakan fenomena umum dalam kerajaan hewan dan masyarakat, seperti lingkungan anak-anak, remaja, dan orang dewasa. (Zulkifli,2009)

Permainan tradisional mempunyai nilai besar untuk generasi penerus bangsa dalam rangka berkreasi, berimajinasi, dan media untuk berlatih hidup bermasyarakat. Manfaat permainan tradisional adalah sebagai berikut: 1) Bermain permainan tanpa mengeluarkan uang; 2) Menumbuhkan kreativitas anak; 3) Mengembangkan kecerdasan sosial dan emosional anak; 4) Mendekatkan anak dengan alam; 5) Sebagai media pembelajaran nilai; 7) Mengembangkan keterampilan motorik anak; 8)
Baik untuk kesehatan; 9) Mengoptimalkan kemampuan kognitif anak; 10) Memberikan kegembiraan dan kegembiraan; 11) Bermain lintas usia; 12) Meningkatkan kepekaan artistik anak. (Achroni, 2012) Betapa banyak manfaat yang dapat diperoleh anak dari bermain game, diantaranya adalah gerak fisik, perkembangan kognitif dan sosial emosional.

Permainan tradisional boy-boy merupakan salah satu media yang dapat melatih anak dalam segala aspek perkembangan sosial. Permainan tradisional boy-boyan adalah permainan tradisional yang beranggotakan 5 orang anak atau lebih. Kelompok mereka mencoba membangun piramida dan pecahan batu bata, sedangkan kelompok lainnya berusaha menghancurkan kelompok lawan untuk membangun piramida. Permainan anak laki-laki tradisional biasanya disebut permainan kartu rusak.

Oleh sebab itu Permainan tradisional boyboyan diharapkan dapat membantu anak untuk mengembangkan kemampuan sosial anak seoptimal mungkin dan sesuai dengan tahapan perkembangannya.

\section{KESIMPULAN}

Berdasarkan pengelolahan data dan hasil analisis pembahasan maka dapat disimpulkan permainan tradisional boy-boyan terhadap perkembangan sosial pada anak kelompok B TK Muslimat NU 79 Miftahul Huda Jemundo Taman Sidoarjo. Berdasarkan hasil perhitungan uji hipotesis yang menggunakan uji $t$ didapat bahwa alat permainan tradisional boy-boyan terhadap perkembangan sosial pada anak kelompok B. yang diperkuat dengan hasil analisis data yang diperoleh dengan menggunakan metode kinerja obsevasi dilapangan secara kuantitatif, dan menggunakan rumus $\mathrm{t}$ hitung, dibuktikan bahwa permainan tradisional boy-boyan berpengaruh terhadap perkembangan sosial pada anak kelompok B TK Muslimat NU 79 Miftahul Huda Jemundo Taman Sidoarjo.

Hasil analisis menunjukkan bahwa nilai $\mathrm{t}$ hitung $=7,431$ melebihi dari pada $\mathrm{t}$ tabel 1,711 dengan taraf signifikansi 5\% dengan $\mathrm{N}=24$ yang berarti hipotesis nihil (Ho) ditolak dan hipotesis kerja $\left(H_{1}\right)$ diterima. Hal ini membuktikan bahwa hipotesis kerja $\left(H_{1}\right)$ menyatakan "ada pengaruh yang positif antara 
WAHANA

Volume 72, Nomor 2, Desember 2020

permainan tradisional boy-boyan terhadap perkembangan sosial anak usia dini kelompok B TK Muslimat NU 79 Miftahul Huda Jemundo Taman Sidoarjo. Dengan demikian dapat disimpulkan bahwa permainan tradisional boyboyan berpengaruh terhadap perkembangan sosial anak usia dini.

Penulis menawarkan saran berikut: (1) Untuk guru Sebagai sarana pembelajaran untuk meningkatkan perkembangan sosial anak sebaiknya guru lebih berpusat untuk mencari permainan yang bisa membuat anak meningkatkan perkembangan sosial pada anak didiknya karena dalam permainan diutamakan untuk selalu mentaati aturan bermain, mau bermain dengan teman sebaya, menunggu giliran bermain, bersikap berkerjasama dengan teman. (2) Bagi sekolah Diharapkan pada pihak sekolah agar selalu memantau kegiatan anak didik selama bersekolah di sekolah tersebut terutama yang berkaitan dengan perkembangan sosial anak. (3) Bagi orangtua Orang tua diharapkan selalu memberi arahan kepada anak ketika anak berada di rumah tentang sosial kepada semua orang disekitarnya. (4) Bagi peneliti selanjutnya,Diharapkan dapat memberikan ide-ide baru dan dapat melanjutkan penelitian ini dengan mengembangkan berbagai aspek yang dapat dikembangkan melalui Permainan Tradisional "Boy-boyan" ini misalnya aspek fisik motorik, koginitif, bahasa atau yang lainnya. Dan dapat meneliti dengan subjek dan latar belakang yang berbeda.

\section{DAFTAR PUSTAKA}

Achroni,Keen. 2012. Mengoptimalkan Tumbuh Kembang Anak Melalui Permainan Tradisional. Jogjakarta: Javalitera.

Aisyah, Siti. 2012. Perkembangan dan Konsep Dasar Pengembangan Anak Usia Dini. Tangerang Selatan: Universitas Terbuka.

Depdiknas, 2008. Kamus Besar Bahasa Indonesia, Gramedia: Jakarta

Fauziddin, Mohammad. 2015. Pembelajaran Anak Usia Dini. Bandung: PT Remaja Rosdakarya.

Pradana,,Eka.2013. Pengaruh Permainan

Tradisional Boy-boyan Terhadap

Keterampilan Motorik Kasar Melempar Pada Anak Usia Dini di TK Kartika IV-13 Lawang.
e-ISSN 2654-4954,p-ISSN 0853-4403

http://karya-

ilmiah.um.ac.id/index.php/IK/article/ view/28749, diunduh 25 desember 2018 pukul 12.52 .

Santi, Danar. 2009. Pendidikan Anak Usia Dini Antara Teori dan Praktik. Indonesia: PT Macanan Jaya Cemerlang

Yusuf, Syamsu. 2015.Psikologi Perkembangan Anak Dan Remaja.Bandung: PT remaja rosdakarya 